\title{
KEBERADAAN BAKTERI Escherichia coli PADA AIR PENCUCI IKAN DI PASAR PINASUNGKULAN KAROMBASAN MANADO.
}

\author{
Andris Z Sauyai, Hanny W. Mewengkang, Semuel M. Timbowo
}

Fakultas Perikanan dan Ilmu Kelautan, Universitas Sam Ratulangi, Manado, Sulawesi Utara.

\begin{abstract}
Waterish a chemical compound that is essential for the survival of living beings on this earth. The function of water for life cannot be replaced by other compounds. Therefore, the provision of clean water and enough quality to be one of the critical success factors in the fishing industry. Water is an important medium in the washing solvent fish, because the fish washing can reduce to eliminate hazardous chemicals or microorganisma Water cleaning process is usually done disinfection. Disinfectants are used in the fishing industry is the provision of chemicals, such as chlorine. According Winarno (1993), chlorine has been proven only ideal disinfectant. When put in the water will have immediate effect destroy most microbes. Based on economic calculations, efficiency and ease of use, the use of chlorine is a common method. This study aims to determine the presence of coli forms and E. coli bacteria were isolated from the washing water, the test was conducted at the Laboratory of Microbiology of Fishery Products, Faculty of Fisheries and Marine Sciences, UNSRAT. Analysis Laboratory, the highest number of bacteria in the samples without making a second chlorine (A1): $4.5 \times 103$, and the lowest number of bacteria in samples containing chlorine taking second (A2): $3.3 \times 102$. In addressing the media that the EC Medium tubes positive coli form bacteria which produce acid and gas in the Durham tube. In order to show the EMB media E. coli growth are most numerous in the sample (A1), the washing water without containing chlorine.
\end{abstract}

Keywords: Escherichia coli, clean water, washing water, chlorine.

\section{PENDAHULUAN}

Air merupakan senyawa kimia yang sangat penting bagi kehidupan makhluk hidup di bumi ini. Air merupakan suatu kebutuhan yang tidak dapat ditinggalkan bagi kehidupan manusia, karena air diperlukan untuk bermacam-macam kegiatan seperti minum, pertanian, industri dan perikanan. Dengan mengetahui kualitas air yang digunakan dapat mencegah kontaminasi bakteri patogen yang berasal dari air terhadap produk, sehingga dapat menghindari penolakan produk oleh konsumen.

Air merupakan media pelarut yang penting dalam pencucian ikan, sebab dengan pencucian ikan dapat mengurangi sampai menghilangkan bahan kimia ataupun mikro organisme berbahaya. Air tempat yang cocok untuk perkembangbiakan mikroba yang bersifat pathogen. Menurut Sri laksmi (1988), mikroba patogen utama dari air yang berasal dari kotoran manusia diantaranya yaitu, Salmonella, Shigella, Vibrio cholera, dan Escherichia coli. E. coli merupakan bakteri indikator terhadap kontaminasi fases terhadap air. Selanjutnya Winarno (1986), menyatakan bahwa air yang digunakan untuk pencucian harus memenuhi persyaratan air minum. Standar kualitas air minum secara mikrobiologis sesuai SNI 010220-87 adalah tidak terdapat bakteri golongan koli dalam $100 \mathrm{ml}$ sampel air (Anonimous, 1987). Menurut Volk dan Wheeler (1990), air terkontaminasi adalah air yang mengandung bahan kimia yang beracun atau organisme patogen, walaupun kelihatan jernih dan cemerlang.

Bakteri koliform antara lain bersifat aerob atau anaerob fakultatif, termasuk ke dalam bakteri gram negatif, tidak membentuk spora, dan dapat memfermentasi laktosauntuk menghasilkan asam dan gas pada suhu $35-$ $37 \mathrm{C}$. Contoh bakteri koliform antara lain Escherichia coli, Salmonella sp., Citrobacter, Enterobacter, Klebsiella, dll. E. coli merupakan mikro organisme indikator yang dipakai di dalam analisis air untuk menguji adanya pencemaran oleh tinja, tetapi pemindah sebarannya tidak selalu melalui air, melainkan dipindah sebarkan melalui kegiatan tangan ke mulut atau dengan pemindahan pasif melalui makanan atau minuman. Ciri-ciri E.coli bentuk batang, biasanya berukuran $0,5 \times 1,3 \mu$ terdapat sendiri, berpasang-pasangan dan rangkaian pendek, bergerak atau tidak bergerak, bergerak 
dengan menggunakan flagella peritrik biasanya tidak berbentuk kapsul, tidak membentuk spora, Gram negatif, Aerob, atau anaerob fakultatif.

Menurut linsley (1991), khlorin telah terbukti merupakan desinfektan yang ideal, bila dimasukkan ke dalam air akan mempunyai pengaruh yang segera akan membinasakan kebanyakan makhluk mikroskopis. Tujuan desinfeksi (khlorinasi) air adalah menginaktifkan organisme-organisme seperti pathogen dan virus yang dapat dipindahkan melalui air. Menurut Winarno dan Sri Laksmi (1974), proses khlorinasi air digunakan khlorin dan gugusannya sebagai bahan pembasmi mikroba (germicidal agent) yang terdapat dalam air.

\section{METODOLOGI PENELITIAN}

Alat yang digunakan dalam penelitian ini adalah autoklaf, mikroskop, timbangan, inkubator, lampu spritus, alumunium foil, botol, kapas, tissue, jarum ose, tabung reaksi, cawan petri, tabung durham, pipet ukur, pipet tetes, oven, gelas ukur, beker glass, ember dan cool box. Bahan baku yang dipakai dalam penelitian ini adalah sampel air pencuci ikan, $\mathrm{NaCl} 0,9 \%$, Nutrien Agar (NA), EMB Agar, EC Medium, Akuades, khlorin atau kaporit $\left[\mathrm{Ca}(\mathrm{OCl})_{2}\right]$.

Penelitian ini bersifat eksploratif yaitu penelitian yang dilakukan untuk mengungkap keterangan suatu fakta secara terperinci dan sistematis (Mantjoro dan Manus, 1987).

Parameter yang di teliti: air pencuci ikan $\left(\mathrm{A}_{1}\right)$, air pencuci ikan mengandung khlorin $5 \%\left(\mathrm{~A}_{2}\right)$. Pengujian mikrobiologis air dapat dilakukan dengan cara: uji jumlah mikroba (Total Plate Count),dengan Metode tuang, uji kualitatif kolifrom dan uji kuantitatif koliform MPN (Fardiaz, (1993), Ijong (2003)).

\section{HASIL DAN PEMBAHASAN}

\section{Analisa Total Plate Count (TPC)}

Tabel 1. Total bakteri.

\begin{tabular}{cc}
\hline Sampel & TPC (CFU/ml) \\
\hline $\mathrm{A}_{1}$ & $4,5 \times 10^{3}$ \\
$\mathrm{~A}_{2}$ & $3,3 \times 10^{2}$ \\
\hline Ket.: CFU (Coloni Forming Unit), TPC (Total Plate Count).
\end{tabular}

Dengan menggunakan metode TPC dapat diketahui jumlah bakteri pada sampel air pencuci ikan. Jumlah bakteri tertinggi pada sampel tanpa khlorin $\left(\mathrm{A}_{1}\right) 4,15 \times 10^{3}$ dan jumlah bakteri terendah pada sampel yang mengandung khlorin $\left(\mathrm{A}_{2}\right) 3,3 \times 10^{2}$. Dari data yang didapat, air yang digunakan belum memenuhi persyaratan untuk digunakan dalam pencucian sebab dalam sampel air ditemukan adanya bakteri. Menurut Schlegel dan Schmidt (1994) jumlah bakteri dalam air harus di bawah 100 $\mathrm{sel} / \mathrm{ml}$.

\section{Analisa Total Koliform \\ Pengujian total koliform menggunakan} media EC medium dan media EMB Agar. Dalam media EC medium menunjukkan bahwa tabung positif adalah bakteri koliform yang menghasilkan asam dan gas dalam tabung durham. Hasil pengamatan pada media EMB Agar menunjukkan pertumbuhan $E$. coli paling banyak terdapat pada sampel $\left(A_{1}\right)$, air pencuci tanpa mengandung khlorin. Sedangkan air mengandung khlorin $\left(\mathrm{A}_{2}\right)$ sedikit pertumbuhan E. coli.

Tabel 2. Jumlah Koliform dan E. coli.

\begin{tabular}{ccccc}
\hline Sampel & \multicolumn{2}{c}{ Jumlah Tabung } & Tang Positif \\
& $\mathbf{1 0}^{-\mathbf{1}}$ & $\mathbf{1 0}^{-\mathbf{2}}$ & $\mathbf{1 0}^{-\mathbf{3}}$ & $\begin{array}{c}\text { Total Koliform } \\
\text { (MPN / 100 ml) }\end{array}$ \\
\hline $\mathrm{A}_{1}$ & 3 & 3 & 3 & $>2.400$ \\
$\mathrm{~A}_{2}$ & 3 & 3 & 0 & 240 \\
\hline
\end{tabular}

Penambahan khlorin pada air yang terkontaminasi begitu efektif untuk membunuh bakteri patogen. E. coli tumbuh pada media yang mengandung khlorin 5\% harus berusaha beradaptasi dengan lingkungan tersebut. E. coli tidak mampu beradaptasi dengan baik karena pengaruh khlorin. Semakin tinggi khlorin yang diberikan semakin lama $E$. coli beradaptasi dan semakin lama pula pertumbuhan. E. coli yang mampu bertahan hidup akibat pengaruh khlorin, akan kembali bertumbuh normal sampai pertumbuhan optimum dan mengalami tahap kematian.

\section{KESIMPULAN}

Dari hasil penelitian dapat diambil kesimpulan:

1. Total bakteri tertinggi pada sampel tanpa mengandung khlorin $\left(\mathrm{A}_{1}\right) \quad 4,5 \times 10^{3}$ dan terendah pada sampel $\left(\mathrm{A}_{2}\right)$ yang mengandung khlorin $3,3 \times 10^{2}$.

2. Jumlah bakteri secara umum, total koliform dan E. coli lebih banyak ditemukan pada sampel yang tidak mengandung khlorin dibandingkan dengan sampel yang mengandung khlorin. 
3. Adanya bakteri koli dan E. coli pada air pencuci dipengaruhi oleh sanitasi lingkungan sekitar sumber air.

\section{DAFTAR PUSTAKA}

Alaerts, G. A, Santika, S. S, 1987. Metode Penelitian Air. Usaha Nasional. Surabaya

Annonimous, 1987.Standar Nasional Indonesia (SNI). Air Minum, Syarat Dan Pengawasan. Jakarta

Buckle, K. A. Edwards, R. A. Fleet, G. H, Wooton, M. 1987. Ilmu Pangan. Penerjemah : Hari Adiono. Penerbit Universitas Indonesia. Jakarta

Cappuccino, J. G. dan Sherman N, 1992.Microbiolgy A Laboratory Manual. Third Edition. Benjamin/ Cumings Science Publishing. California

Fardiaz, S, 1982. Mikrobiologi Pangan. Penuntun Praktek Laboratorium. Jurusan Ilmu Dan Teknologi Pangan. Fakultas Pertanian. IPB.Bogor.

Ijong, F. G., 2003. Penuntun Praktikum Mikrobiologi Pangan Ikani. Fakultas Perikanan Dan Ilmu Kelautan. UNSRAT. Manado
Linsley, 1991.Teknik Sumber Daya Air, Jilid II. Penerjemah : Ir. Djoko Sasongko. Erlangga. Jakarta.

Mantjoro, M. E. Manus, O, 1987. Pengantar Kuliah Filsafat Ilmu. Fakultas Perikanan. UNSRAT.

Schlegel,G. H, Schmidt, K, 1994. Mikrobiologi Umum. Penerjemah Prof.J.R. Wattimena. Gadjah Mada University Press. Yogyakarta.

Sri Laksmi, B. J. 1988. Sanitasi Dalam Industri Pangan. Penerbit Kanisius Kerjasama Dengan Pusat Antar Universitas Pangan Dan Gisi, IPB. Bogor

Suriawiria, U. 1986, Mikrobiologi Air. Penerbit Alumni. Bandung.

Volk, W. A., Wheeler, M. F. 1990.Mikrobiologi Dasar Jilid 2. Erlangga. Jakarta.

Winarno, 1979.Teknologi Pangan. PT Gramedia. Jakarta

Winarno, F. G. Dan Sri Laksmi, B. J. 1974. Sanitasi Dan Keracunan. Departemen Teknologi Hasil Pertanian, IPB. Bogor. 